\title{
The debate on the structure of 1 John
}

\author{
P J van Staden \\ University of Pretoria
}

\begin{abstract}
The lack of consensus concerning the structure of 1 John applies to the division in main sections and the subdivisions of each main section, as well as to the proposed themes for the various sections. In this paper the opinions of some of the most prominent scholars are shortly discussed and assessed. In this procedure the scholar's proposals for the different transitions of the main sections and subsections are critically scrutinised. In the new proposal that follows, the view is expressed that, if certain literary features such as chiasms and parallelisms are duly taken in consideration, it can be asserted that 1 John does display a coherent structure of some sort.
\end{abstract}

\section{DIVERSE OPINIONS REGARDING THE STRUCTURE OF 1 JOHN}

The opinions of scholars find expression in four main categories. First, that the overall structure involves a substantial expansion of an already existing source; second, that the letter consists of independent units that cannot be joined into major unitary sections; third and fourth, that it can be divided in respectively two and three main sections.

1.1 The latter part of the Letter as an extension of a first pre-existing part (Grayston 1984)

While Bultmann (1973:1-3) views $1 \mathrm{Jn}$ 1:5-2:2 as an independent document or rather a rough draft, Grayston (1984) considers 1:1, 2-2:11 (with the exception of 2:1-2, 7-8) an existing writing. This original writing was meant as an appeal to a group who

- This article is based on a chapter of the dissertation (1988) 'Die struktuur van die eerste Johannesbrief. The dissertation with prof dr G M M Pelser as promoter was submitted and accepted as part of the requirements for the DD degree, Faculty of Theology ( $\operatorname{Sec} A$ ), University of Pretoria. 
appeared to be interpreters and guardians of tradition and who also invited another group to mutual fellowship. 'Their appeal rests upon a carefully formulated understanding of the tradition which chiefly refers to keeping the commandments of love and to the model of Jesus as guide to our actions and his death as remedy for our faults.' In Grayston's (1984:3) view the two interpolations (2:1-2; 2:7-8) respectively prepare the way for what follow in the two main sections of the expansion (2:15$3: 10 ; 3: 11-4: 21)$. In each of these basically polemical main sections which follows the transitional passage of $2: 12-14$, the two themes of the original writing, namely keeping the commandment of love and adhering to Jesus as model, are discussed more comprehensively. These two sections are organised around the two themes of the interpolations (the end of the old cosmos 2:1-2 and the old commandment, and the transition into the new cosmos 2:7-8) and are built around two attacks on the dissident group (2:18-25; $4: 1-12)$. The concluding section (5:1-13) contains yet a third, less diffident attack on the dissidents, while 5:14-17 can be considered a postscript/epilogue much like John 21 dealing with casuistry, and 5:18-21 a possible later addition.

The view of Grayston is unacceptable for most scholars. Source criticism of such proportions is no longer a viable option with respect to $1 \mathrm{John}$ and should be avoided (cf Segovia 1987:134).

\subsection{Divisions into isolated sections (Marshall; Kysar)}

Against Bonnard (1983) as quoted by Segovia (1987:132-133), who proposes a division into fifteen units, Marshall (1978:26) regards 1 John as consisting of twelve sections whose relations to one another are governed by means of association of ideas rather than logical plan. These sections correspond to a large extent with the eleven sections defined by O'Neill (1966:1-6).

Kysar (1986), whose division of seven sections corresponds mainly with the seven designated by Houlden (1973:22-25), considers $1 \mathrm{John}$ as comprising fragments of messages about various topics, perhaps all relating to a dissension crisis within a Christian community. It can probably be viewed as 'a kind of anthology of bits of sermons patched together and rendered into a written form for circulation' (Kysar 1986:16). Obviously the author is defending his readers against the threat of separatists by emphasising the incorrectness of their beliefs and assuring his readers of their consistency with the traditional faith. The 'lines of distinction' between them and the separatists 'must be sharply drawn, leaving no doubt as to the difference between them' (Kysar 1986:20).

Although no logical order according to modern criteria exists, the structure of the document possesses a kind of power in its own right. This 'power' can be seen 
firstly in the dialectical nature of the major parts, in which each part poses two topics and explores the interrelationship between them. In addition, each major part is connected with the preceding, by means of a word or concept association while, thirdly, each major part consists of three subparts (Kysar 1986:27).

In view of the recurrence of a few themes through the whole of the Letter, the division into seven to twelve isolated sections is an unacceptable solution for the majority of scholars.

\subsection{Division into two main sections (Brown; Smalley)}

While Plummer (1954:43) regards the main part of the Letter as diverging into two fairly equal halves, namely 1:5-2:25 (God is light) and 2:29-5:12 (God is love), Brown (1982: 128; cf Culpepper 1985), with reference to Feuillet (1973), argues for the conception of the structure of 1 John as resembling the Gospel of John. It is not a question of exact similarity but only 'a simple basic pattern that presumably shaped Johannine tradition...where one considers first and polemically those who do not believe, then second and lovingly those who do believe'.

Like the Gospet, the Letter consists of a peculiar prologue, two major sections and a conclusion. The division between the main parts is, however, not so sharp in the case of the Letter as it seems to be between John 12 and 13.

Although 3:1 can be considered as the beginning of the second main part (Feuillet 1973), 3:11 is preferable as the beginning because both major sections would then be corresponding with each other with respect to their length as well as their beginning with the formula 'this is the gospel'. As a $y \gamma \in \lambda$ ia was most probably the community's title for the Gospel of John, this peculiar usage looks like a key applied by the author to indicate a transition. Significantly the formula provides the main theme for each section in question, namely 'God is light - we must walk in the light as Jesus walked', and 'love one another as God has loved us in Jesus Christ'.

According to Smalley (1984:xxxvii) $1 \mathrm{John}$ is a 'paper' that 'explicates the teaching of the Gospel of John and develops it, indicating at the same time how it should properly be interpreted', but it need 'not be regarded as some kind of deliberately patterned comment' on the Fourth Gospel (thus Brown). The Letter displays a close literary unity, with the basic coherence and balance being two of its essential features (Smalley 1984:xxxvii).

Each of the two major sections, namely 1:5-2:29 (live in the light) and 3:1-5:13 (live as children of God) begins with an introductory statement, respectively 1:5-7 (God is light) and 3:1-3 (God is Father), followed by four basic conditions for true Christian living. These conditions are spelled out in the first half and repeated in a 
cyclical fashion, with one expansion, during the second half. 'The symmetry in both halves of 1 John is thus virtually perfect' (Smalley 1984:139).

The division of the Letter into two main sections does not account for the cyclical occurrence of the three 'love sections' as does the three-section division which follows. (In the two sections hypothesis units are to a large extent forced into categories which do not adequately fit them, e $\mathrm{g}$ 4:1-6, which is included by Brown in the section concerning love for one another, while Smalley views this as a call to reject worldliness.) In addition, the transitions after 2:29 and 3:10 (as propounded by exponents of the two-main-sections hypothesis) are syntactically far less acceptable.

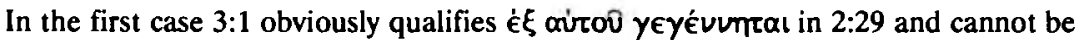
considered a new unit of thought. This applies also to $3: 11$, which is a causal

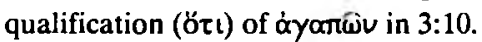

Brown's (1979) opinion, namely that the overall structure of the Gospel is followed by the Letter, is unconvincing because the proposed patterning is not that explicit or evident (cf Segovia 1987:134). Brown (1979, 1982; cf Culpepper 1975: 283), however, contributed largely to this debate by the theory that the Letter was meant to explicate theological themes in the Gospel apologetically against the claims (also grounded in the Gospel) of the opponents. More about this follows in the conclusion.

\subsection{Division into three main sections}

In the category of the division into three main sections, scholars locate the transition between the first and second sections either after $2: 17$ or after $2: 27,28$ or 29 , and the transition between the second and the third after either 3:24 or 4:6. Regarding this category there are therefore four alternatives, namely transitions after $2: 27$ and $3: 24,2: 17$ and $4: 6,2: 27$ and $4: 6,2: 17$ and $3: 24$.

Dodd (1947) is the only scholar to allocate a transition after 4:12. His proposed themes for the main sections are: 'what is Christianity' (1:5-2:28); 'life in the family of God' (2:29-4:12); 'the certainity of faith' (4:13-5:13).

\subsubsection{Transitions after 2:27 and 3:24 (Balz)}

Balz (1973:160) considers the first main section (1:5-2:27) as consisting of six antitheses, in which the wrong disposition of the dissidents is contrasted with the proper life of the community. In two isolated units the 'konkreten Fronten' are defined: in 2:12-17 the community, and in 2:18-25 the 'endzeitlichen Christusleugner'. In the second section (2:28-3:24) the practical life of those who belong to God is contrasted with that of those who belong to the devil. In the third it is stressed, with refe- 
rence to the key words 'love' and 'faith' in 3:23, that the right faith entails the right life practice.

\subsubsection{Transitions after 2:17 and 4:6 (Du Rand)}

Du Rand $(1981,1983)$ argues that, although an impression of a kaleidoscopic variety of subjects is created, the Letter has a unified line of thought, namely the identity of the readers. This identity is marked by their fellowship with God on the one hand, and the assuredness of the possession of eternal life on the other. Both can be viewed as two sides of the same coin, fellowship as the objective and assuredness as the subjective side. The latter can be experienced in fellowship, childhood and love, three aspects focussed upon respectively in each of the three main sections. In each main section these aspects are elaborated on in terms of their 'foundation', 'criterion' and 'test'. An account of the testimony about Jesus Christ (5:6-13), and a summary (5:14-21) conclude the Letter.

The opinions of Balz and Du Rand have won little support among scholars. Both neglect the important interrelationship of love $(2: 7-11 ; 3: 10-17 ; 4: 7-16)$ and faith $(2: 20-27 ; 4: 1-6)$ in each main section, which is accounted for in the next two subcategories $(1.4 .3 ; 1.4 .4)$.

\subsubsection{Transitions after 2:27 and 4:6 (Malatesta; Stott)}

Malatesta (1978; cf also Nagl 1924; Jones 1970) maintains that each of the three main sections contains prominent utterances concerning God, namely light (cf 1:5), righteousness ( $\mathrm{cf} 2: 29$ ) and love (cf 4:8). He is of the opinion that the key to the understanding of the Letter is the so-called 'Christian interiority, $\mathrm{i}$ e the conscious awareness of communion with the Father in and through Jesus Christ, and of the gifts that enable and the obstacles that hinder such communion' (Malatesta 1978:2).

While the entire Letter deals with criteria for fellowship, the development with regard to the relationship between the themes of faith and love is prominent in each main section. While they are mentioned separately in the first two main sections (2:3-11 love; $2: 12-28$ faith; $3: 11-24$ love; $4: 1-6$ faith), the focus in the third section is on their mutual correlation.

The viewpoint of Stott (1976) is categorised here although he proposes a division of the Letter in five main sections. The reason for doing this is that he applies three cycles of tests for fellowship with God as the point of departure for dividing the Letter in three central main sections. The three cycles of tests in each main section consisting of the theological (faith), moral (righteousness) and social (brotherly love) criteria, are reminiscent of the conventional 'three-division' scheme of Law (1909) and Haring (cf Brooke 1912). According to Law the key to the interpre- 
tation of the text is that it is an 'apparatus of tests' (Law 1909:6) through which the readers are supplied with criteria so that they can be sure of their fellowship with God.

Scholars like Malatesta and Stott who opt for this view (i e transitions after 2:7 and 4:6) have, by placing $2: 18-27$ in the first cycle, neglected the fact that $1: 5-2: 2$ already deals with faith (as the foundation of love). The confession of sins indeed implies faith in God and Jesus, and indicates the abiding of such a person in the truth and in the word (1:8,10; cf $\dot{\alpha} \lambda \dot{n} \theta \in \operatorname{\alpha } \alpha$ in 2:20-27).

An important reason for regarding $2: 18$ as the beginning of the second main part, is that $2: 18-19$ introduces $2: 18-3: 17$ with the words 'the last hour' (2:18; cf

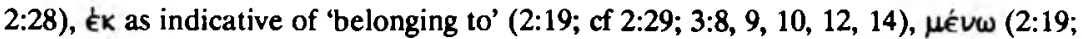
cf $2: 24,27,28 ; 3: 6,14)$, and фavepó $(2: 19 ;$ cf $2: 28 ; 3: 2,5,8)$. Likewise $4: 1-6$ should be regarded as part of the third main section because 3:18-24 figures as obvious conclusion of the first two main sections and as a transition to the third (as will be pointed out below).

\subsubsection{Transitions after 2:17 and 3:24 (Thüsing; Schnackenburg; Wengst; Schunack)}

Thüsing (1970:19-21) argues that the structure of the Letter may best be comprehended by the discernment of three themes in each of the three main sections. These themes are 'faith in Christ', 'love' and 'the Christian and sin' (which represents the negative aspect of love). Unlike the other scholars mentioned in this paper he incorporates the prologue (1:1-4) and a part of the conclusion (5:13-18) in the first and third main parts respectively." This is incorrect and is due to the fact that he fails to observe the correspondence between 'faith' and 'the Christian and sin' (see the next section).

Schnackenburg (1963), who largely elaborates on the structure proposed by Schneider (1967; cf Hauck 1949), correctly points out that the theme of fellowship with God, which is mentioned in the prologue, is developed in the first main section (1:5-2:17) by stressing the condition for this fellowship as 'walking in the light'. He is also correct in his observation that 1:5 introduces this whole section. The second main section (2:18-3:24) deals with the present situation of the Christian community.

- Du Plessis and Fleinert-Jensen also include the prologue and conclusion. According to Du Plessis (1978:9-11) the three sections deal with fellowship in general (1:1-2:17), the threat and safeguard to the fellowship (2:18-3:24), and the configuration of the fellowship, namely faith and love (4:1-5:21). Flcinert-Jensen (1982 as quoted by Segovia 1987:133) argues that the Letter does not present a precise or systematic line of development but can, however, be divided into three major literary sections based on the different positions taken by the author against the adversaries. Firstly, there is an indirect approach in 1:1-2:17, then a first attack, followed by a series of moral and doctrinal observations in 2:18-3:24 and, lastly, a second attack followed by doctrinal and moral reflections in 4:1-5:21. 
The motif of fellowship with God is placed now in the eschatological perspective of the 'last hour'.

In the third section ( $4: 1-5: 12)$ the aspects of faith and brotherly love, mentioned in 3:23 as discerning signs of Christianity in contrast with the world, are developed. Schnackenburg is correct in observing that an ABA1 schema can be discerned on account of the focus on faith (4:1-6), love (4:7-5:4), and again faith (5:5-12).

Wengst (1978) agrees largely with Schnackenburg's scheme for the overall structure. He considers the first section mainly ethically and the second (with Schnackenburg) eschatologically determined. In agreement with Schnackenburg he also views the third section as focusing on faith and brotherly love (with reference to 3:23) as two inseparable aspects of the one criterion for true Christianity. However, by beginning a new subsection at 5:1, he loses sight of the important ABA1 schema of Schnackenburg.

The mutually corresponding proposals of Schnackenburg and Wengst do justice to the structure of the text to a large extent. Their proposals for the main themes of the text, however, do not display a satisfactory central line of thought for the Letter.

Schunack (1982:14-15; cf Segovia 1987:133) considers that 1 John does not present a precise or systematic line of development of thought. However, it can be divided into major sections on the basis of certain overarching theological ideas. This division is based on the belief that the document presents an explanation of the community of believers both in terms of its grounding and its reality. The believers are participating in eternal life, which is grounded in the love of God, which in turn has been realised in Christ.

The following themes for the main sections are proposed: fellowship with God and knowledge of God in the light of brotherly love (1:5-2:17); the prominence of God's love for salvation in Jesus Christ (2:18-3:24); the testimony of the Spirit in the knowledge of faith (4:1-5:12). The three main sections can be associated with the Father, Son and Spirit respectively." 'Es erscheint nicht zu weit gegriffen, den innere Zusammenhalt vergewissernder Auslegung des Christseins in 1 John 1:5-5:12 trinitätstheologisch zu bestimmen' (Schunack 1982:15).

Although Schunack did not succeed in detecting a systematic line of development in the Letter and did not prove his point convincingly, his notion of the assosiation of the three main sections with the triad is certainly not far-fetched (see note 3). The insight that the whole of the third section can be associated with the Spirit can present an especially important key for a better understanding of the structure of the Letter (as will be discussed in the proposal that follows).

- Hort (Wesicott \& Hort 1907:485) already associated the three main parts (of which the most important themes are respectively obedience, love and (aith) with the triad Father, Son and Spirit. 


\section{PROPOSED SOLUTION}

The view and thesis expressed in this part of the paper is that the observance of the so-called chiastic style presents an important key to a better understanding of the structure of $I$ John. A closely structured unity with a notable central line of thought can be detected when the arrangement of brief passages and also larger groups of passages in chiastic and alternating (parallelistic) patterns, or combinations of both, are properly taken into consideration."

In the discussion that follows a few remarks are firstly offered about the chiastic style and its possible use in the analysis of $1 \mathrm{John}$. Secondly, a brief schematic overview of the structure as well as an exposition of the themes is presented. This is followed by conclusive arguments.

\subsection{Chiastic structure and style, and 1 John}

Lund $(1931: 47 ; 1932: 30)$ correctly points out that many passages in the Old and New Testaments that are regarded as loose and verbose with inelegant tautologies are really specimens of the chiastic style, which as a literary form has as much claim to our consideration as any other style of writing. According to Lund, this Semitic custom of making use of literary figures such as chiasms and parallelisms was used extensively in the Greek of the New Testament (also in documents which no one suspects of being translations). Once this phenomenon is considered, passages which have formerly seemed monotonous will be rediscovered as having a literary charm and fascination of their own (Lund 1941:30-31). To my mind this insight applies also to $1 \mathrm{John}$ which has even been called 'the rambling prattle of an old man' (Plummer 1954:41).

Since the appearance of Lund's book in 1942, many studies have identified chiastic structures in most of the books of the New Testament; a considerable number appears in the Gospel of John (Culpepper 1981:3, 7). In this respect the works of Culpepper (1981), Giblin (1984) and Staley (1986) are worth mentioning. The so-called 'broken logic' (cf Painter 1984:462) in the prologue of John's Gospel is convincingly traced back by them to the chiastic style.

The Gospel's tendency towards the chiastic style might be significant for the interpretation of the Letter. The substantiation of the hypothesis of chiastic patterns and parallelisms in 1 John must, however, be done by analysis of this Letter alone, and not via themes and patterns in the Gospel. In view of the widely accept-

- Culpepper (1982:8) applies three criteria for chiasms: language, concepts and content. Bar-Efrat (1980:155) mentions four levels on which the inversion or repetition can occur. As in Lund (1942:31) the term 'chiasm' in this study designates every repeated inversion. Bar-Efrat (1980:17) on the other hand distinguisbes between ring (ABA1), chiastic (ABB1A1), and concentric (ABCB1A1) patterns. 
ed theory, which I endorse, that 1 John is a 'legimitate' presentation of the truth of the Gospel against the 'heretical' understanding of the Gospel by the opponents, it can be expected that the contents and also the style of the Gospel will give important clues for understanding the Letter. If the author of 1 John indeed wanted to present himself as the real interpreter of the Gospel, he probably would have made his writing correspond largely with the Gospel. Accordingly, it should stand beyond doubt that many concepts and motifs in the Letter derive from the Gospel. This is my working hypothesis, although I am well aware of the fact that scholars differ widely on this issue.

Bearing all this in mind, it is certainly not far-fetched to expect that the investigation of the structure, with due consideration to the literary figures, can furnish important information for a better understanding of the Letter. Structural arguments, amongst other things, usually prove to be very helpful in determining the boundaries of the literary units and proving the unity of a document (Bar-Efrat 1980:172). As can be gathered from the first part of this study, the fixing of boundaries and establishing the unity of the document are major problems in studies of 1 John.

\subsection{Schematic overview}

In the schematic overview at the end of this article, the three main sections are placed next to each other while they are also divided into subsections (e g I, II), which in turn are divided into concentrically arranged parts (e g ABA1). Generally, each of these parts are structured chiastically or parallelistically.

The uniformity between the first two main sections, in particular, is obvious: In each of the four subsections (I, II) the parallel parts (B) are framed by the chiastic parts (A, A1); in I of both sections the chiasms' centres comprise a lie-truth antithesis. In II the chiastic parts (A, A1) deal with either brotherly love or worldly notlove.

With reference to the third main section, subsections I, II, IV and V, each consisting of five chiastic parts (A, B, C, B1, A1) are also concentrically structured around III.

\subsection{Exposition of themes}

First section (1:5-2:17): Brotherly love, grounded in faith as andication of knowledge of God, the eternal light. 


\section{Introduction (1:5): Content of the kerygma: God is light;}

I 1:6-2:6: The keeping of the commandments (=walking in the light), grounded on confession as an indication of knowledge of God ( $=$ fellowship with the light);

A 1:6-7: Walking in the light as indication of fellowship with the light (truth);

B 1:8-2:2: Cleansing of sin for everyone in whom the word dwells (who confesses sin and thus expiation) as the foundation of this fellowship;

A1 2:3-6: Keeping the commandments as indication of the knowledge of God;

II 2:7-17: Brotherly love contrasted with love of the world, as indication of fellowship with God, the eternal light;

A 2:7-11: Brotherly love as indication of the adherence to the eternal era of light;

B 2:12-14: Assurance/admonition: forgiveness of sins (see 1:6-2:2), knowledge of God (see 2:3-6), and consequently victory grounded in the knowledge of Jesus through the indwelling word;

A1 2:15-17: Not loving the world as indication of fellowship with the Father and thus of eternal life.

Second section (2:18-3:17): Brotherly love, grounded in faith as indication of the fellowship with the Son of God (= childhood of God).

Introduction (2:18-19): The present manifestation of the antichrist in the opponents of the community;

I 2:20-27: The confession of Jesus as Christ, based on the original proclamation, as indication of fellowship with Christ;

A 2:20-23: The irreconcilability of the truth and lie represented amongst the readers with the Christ, and the antichrist who denies the confession of Jesus as Christ;

B 2:23-25: The abiding in the original kerygma as the foundation of fellowship with the Son, and therefore with the Father and eternal life;

A1 2:26-27: The sufficiency of the present teaching of the indwelling charisma (the same truth as the past teaching of Christ) for fellowship with Christ; 
II 2:28-3:17: Being hated by the world and having love for one's brother as indication of sonship of God;

A 2:28-29: Being hated (not known) by the world (on account of being loved by God), and being righteous as the present manifestation of childship of God; to be changed by the future manifestation of the Son;

B 3:4-9: Assurance and admonition (as 2:12-14): delivered from sin (cf Jn 8:34), grounded in the past manifestation of the Son for everyone in fellowship with him (cf 2:27, 28), everyone who is a child of God (cf

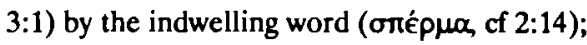

A1 3:10-17: Hate and love (righteousness) as present manifestation of the childhood of the devil and of God; hate, connected to Cain who took his brother's life, as indication of death; love connected to the Son of God (who gave his life) as indication of life ( $\zeta \omega n$ ) for everyone who is willing in turn to give his own life ( $\psi v \times \dot{\eta})$ and does not cling to the life (Bios) of the world.

Conclusion of the first and second sections and transition to the third (3:18-24): observance of the commandments of faith and love as criteria of fellowship with God and therefore of surety based on the greatness of God's love; this fellowship is knowable by the Spirit as gift.

Third main section (4:1-5:12): Love for one another, grounded in the word-based faith in the humanity of Jesus, as indication of the Spirit as gift.

Introduction (4:1): Testing of the spirits;

I 4:2-6: Word-based faith as indication of the Spirit of God;

AB 4:2-3: Confession of the humanity of Jesus as indication of the Spirit of God;

C 4:4-5: Victory grounded in the indwelling word;

B1A1 4:5: Listening to the faithful witnesses as indication of the Spirit of truth;

II 4:7-16: Love grounded in faith as indication of the Spirit;

A 4:7-8: Love for one another as indication of fellowship with God, the very source of love;

B 4:9-12a: Love for one another as indication of the perception of the concretised love of God in Jesus; 
C 4:12b: Love for one another as indication of fellowship and perfection of the goal of God's love and consequently indication of the Spirit as gift;

B1 4:14-15: Seeing and witnessing (cf $1 ; 2$ ) of the concretised love of God in Jesus (faith to confess) as fruit of the Spirit;

A1 4:16: Belief in the love of God as fruit of the Spirit;

III 4:17-18: Assuredness and not fear as fruit of the perfection of God's love;

IV 4:19-5:4: Faith in Jesus Christ as the foundation of love for one another;

A 4:19: Love grounded in God's love (4:7-16);

B 4:20: The need for the concretising love towards the visible brother;

C 4:21-5:1: The self-evident obedience to the love commandment of a Jesus-confessing son of God for a fellow son of God;

B1 5:2-3a: The need for genuine brotherly love to be grounded in the love of God;

A1 5:3b-4: The grounding in faith of the victory over the world (for whom the love commandment is burdensome);

$\mathrm{V}$ The testimony of life through Jesus' death as indication of the Spirit of truth;

A 5:5-6a: The humanity of jesus as the content of faith;

B 5:6b: The testimony of the Spirit as truth;

C 5:7-8: The like-mindedness of the witnesses;

B1 5:9-10: The testimony about the Son as the testimony of God;

A1 5:11: Life in the Son as content of the testimony.

\subsection{Conclusion}

In the final analysis it is obviously necessary to substantiate the above-mentioned hypothesis that the Letter is an apologetic document based on the Gospel of John. As indicated, $1 \mathrm{John}$ was written to refute the opponents' claims, which were seemingly drawn from the Gospel. It is also of cardinal importance to account for the function of the prologue (1:1.4) and the conclusion (especially 5:13) of the Letter. 
According to 1:3, the purpose of the author's proclamation is that the fellowship of the readers with him as one of the faithful witnesses should be maintained (Marshall 1978:105). It thus entails the maintaining of fellowship with the Father and the Son (1:3) and consequently with eternal life (1:1, 2; of 5:13). To meet this end the author deals with three major issues, namely fellowship with the light, sonship of God (which correlates with fellowship with the Son of God), and the reception of the Spirit of God as gift." Obviously all of these are major themes in the Gospel of John as well (cf Jn 1:4, 12; 8:31ff; 14-16, etc). The opponents probably claimed, on account of their perception of the Gospel, that all these had already been realised in their lives.

In his refutation of the claims of the opponents, the author states that faith and brotherly love are the indications of fellowship with the light (section 1), sonship of God (section 2), and the Spirit as gift (section 3). This truth can be viewed as being fully in accordance with the Gospel. Brotherly love, however, must be grounded in faith in the truth of the humanity of Jesus, and true life is only possible through his death. By perceiving of the sacrifice of Jesus' life as manifestation of God's love, it becomes possible to respond with genuine brotherly love. The opponents (with their gnostic tendencies) who have neglected this basic truth do not therefore have the faith and corresponding brotherly love which are indicative of fellowship with God and the possession of eternal life.

This truth (word) of the manifestation of life through death is the original kerygma ('word' $1: 1$ ) that was handed down by the faithful witnesses like John the Baptist (Jn 1:34) and the Beloved Disciple (Jn 19:35) who 'saw and witnessed' (Christ, the Word that 'witnessed' what he 'saw' from the Father, was probably implied). By stressing the fact in 1:2 that he himself 'saw and witnessed', the author presents himself as one in the line of the faithful witnesses. By maintaining the fellowship with the community (1:3), the original line of the word and therefore of the light, the love and the life, will not be broken, as happened in the case of the opponents.

What about the conduct of the readers towards the opponents? The opponents discontinued the line to the Light and the Love, the source of knowledge and brotherly love. It is therefore appropriate for the children of God not to be known to the world and not to love the world. Any line that still existed between the community and the opponents must be broken.

* It scems that the first and second main sections are associated respectively with 'eternal' (cf $2: 8$, 17 ) and 'life' (3:14). Seemingly 'eternal' (and the first main section) is more associated with fellowship with the Father (2:15, 16; cf 1:2), and 'life' (and the second main section) with fellowship with the Son (cf the theory of Schunack above). 
SCHEMATIC OVERVIEW OF THE STRUCTURE

\begin{tabular}{|c|c|c|}
\hline SECTION 1 & SECTION 2 & SECTION 3 \\
\hline $\begin{array}{l}\text { Introduction: God is } \\
\text { light }(1: 5)\end{array}$ & $\begin{array}{l}\text { Introduction: manifes- } \\
\text { tation of antichrists } \\
(2: 18-19)\end{array}$ & $\begin{array}{l}\text { Introduction: } \\
\text { testing of spirits } \\
(4: 1)\end{array}$ \\
\hline $\begin{array}{l}\text { I } \\
\text { A* lie-outdo truth } \\
(1: 6-7)\end{array}$ & $\begin{array}{l}\text { I no life of truth } \\
A_{(2: 20-22)}\end{array}$ & $\begin{array}{l}\text { I } \\
\text { A faith } \\
\text { B indicative } \\
\text { C of the } \\
\text { B1 spirit } \\
\text { A1 of truth } \\
\quad(4: 2-5)\end{array}$ \\
\hline $\begin{array}{l}B^{* *} \text { foundation of } \\
\text { fellowship } \\
(1: 8-2: 2)\end{array}$ & $\begin{array}{l}\mathrm{B} * \text { * foundation of } \\
\text { fellowship } \\
(2: 23-25)\end{array}$ & $\begin{array}{l}\text { II } \\
\text { A love grounded } \\
\text { in faith in } \\
\text { B God's love } \\
\text { C indicative } \\
\text { B1 of the Spirit } \\
(4: 7-16)\end{array}$ \\
\hline $\begin{array}{l}\text { A1* liar-not truth } \\
(2: 3-6)\end{array}$ & $\begin{array}{c}A 1 * \text { truth-not lie } \\
(2: 26-27)\end{array}$ & \\
\hline $\begin{array}{l}\text { II } \\
\text { A* love-not truth } \\
\quad(2: 7-11)\end{array}$ & $\begin{array}{l}\text { II } \\
A^{*} \text { not-lovi: of } \\
\text { (known by) the } \\
\text { world }(2: 18-3: 3)\end{array}$ & $\begin{array}{l}\text { surety } \\
(4: 17-18)\end{array}$ \\
\hline \multirow[t]{2}{*}{$\begin{array}{c}B^{* *} \text { assurance/ } \\
\text { admonition } \\
(2: 12-14)\end{array}$} & \multirow[t]{2}{*}{$\begin{array}{c}B * * \text { assurance/ } \\
\text { admonition } \\
(3: 4-9)\end{array}$} & $\begin{array}{l}\text { IV } \\
\text { A faith } \\
\text { B as foundation } \\
\text { C of love } \\
\text { B1 }(4: 19-5: 4) \\
\text { A1 }\end{array}$ \\
\hline & & $\begin{array}{l}\text { V } \\
\text { A the } \\
\text { B spirit } \\
\text { C as true } \\
\text { B1 witness }\end{array}$ \\
\hline \multicolumn{2}{|c|}{ Summary and transition: surety $(3: 18-24)$} & (faith) \\
\hline
\end{tabular}

- Chiasm

* Parallelism 


\section{Works cited}

Balz, H 1973. Die Johannesbriefe in Balz, H \& Schrage, W, Die 'Katholischen'Briefe. 11. Aufl. Göttingen: Vandenhoeck. (NTD 10.)

Bar-Efrat, 1980. Some observations on the analysis of structure in biblical narrative. VT 30/2, 154-173.

Brooke, A E 1912. A critical and exegetical commentary on the Johannine epistles. Edinburgh: Clark.

Brown, R E 1979. The community of the Beloved Disciple. New York: Paulist Press.

--- 1982. The Epistles of John. New York: Doubleday \& Company.

Bultmann, R 1973. The Johannine epistles. Philadelphia: Fortress.

Culpepper, R A 1975. The Johannine school hypothesis based on an investigation of the nature of ancient schools. Missoula: Scholars Press. (SBL Dissertation Series 26.)

--- 1981. The pivot of John's prologue. NTS 27, 1-31.

--- 1985. 1 John, 2 John, 3 John. Atlanta: John Knox Press.

Dodd, C H 1947. The Johannine epistles. London: Hodder \& Stoughton.

Du Rand, J A 1981. A discourse analysis of 1 John. Neotestamentica 13, 1-42.

-- 1983. Beleef julle sekerheid: 'n Verkenning van die briewe van Johannes. Pretoria: NG Kerkboekhandel.

Feuillet, A 1973. The structure of First John. Comparison with the 4th Gospel. The pattern of Christian life. BTB 3/2, 194-216.

Giblin, C H 1984. Two complementary literary structures in John 1:1-18. JBL 104, 87-103.

Grayston, K 1984. The Johannine epistles. Grand Rapids: Eerdmans.

Hauck, F 1949. Die Briefe des Jakobus, Petrus, Judas und Johannes. 5. Aufl. Göttingen: Vandenhoeck.

Houlden, J L 1973. A commentary on the Johannine epistles. London: Adam \& Charles Black.

Jones, P R 1970. A structural analysis of 1 John. RExp 67/4, 433-444.

Kotze, P P A 1979. The meaning of 1 John 3:9 with reference to 1 John $1: 8$ and 10. Neotestamentica $13,68-83$.

Kysar, R 1986. 1, 2, 3 John. Minneapolis: M N Augsburg. (Augsburg Commentary on the NT.)

Law, R 1909. The Tests of life: A study of the first epistle of St John. Grand Rapids: Baker Book House.

Lund, N W 1931. The influence of Chiasmus upon the structure of the Gospels. ATR 13, 42-46. 
Lund, N W 1932. Chiasmus in the New Testament. Chapel Hill, N C: University of North Carolina Press.

Malatesta, E 1978. Interiority and Covenant: $A$ study of einai and menein in the first letter of Saint John. Rome: Biblical Institute.

Marshall, I H 1978. The epistles of John. Grand Rapids: Eerdmans.

Nagl, E 1924. Die Gliederung des ersten Johannesbriefes. $B Z$ 16, 77-92.

O'Neill, J C 1966. The puzzle of 1 John: A new examination of origins. London: SPCK.

Painter, J 1984. Christology and the history of the Johannine community in the prologue of the Fourth Gospel. NTS 30, 460-474.

Schnackenburg, R 1963. Die Johannesbriefe. 2. Aufl. Freiburg: Herder.

Schneider, J 1967. Die Kirchenbriefe. Göttingen: Vandenhoeck. (NTD 19.)

Schunack, G 1982. Die Briefe des Johannes. Zürich: Theologischer Verlag. (Zürcher Bibel Kommentar, NT 17.)

Segovia, F F 1987. Recent research in the Johannine letters. Religious Studies Review $13,132-139$.

Smalley, S S 1984. 1, 2, 3 John. Waco: Word Books. (Word Biblical Commentary 51.)

Staley, J 1986. The structure of John's prologue: Its implications for the gospel's narrative structure. $C B Q 48 / 2,241-264$.

Stott, J R W 1976. The epistles of John: An introduction and commentary. Leicester, England: Inter Varsity Press.

Thüsing, W 1970. Die Johannesbriefe. Düsseldorf: Patmos.

Van Staden, P J 1988. Die struktuur van die eerste Johannesbrief. DD Proefskrif, Universiteit van Pretoria.

Wengst, K 1978. Der erste, zweite und dritte Brief des Johannes. Würzburg: Gütersloher Verlagshaus. (Ökumenischer Taschenbuchkommentar zum Neuen Testament 16.)

Westcott, B F 1982. The epistles of St John. 4th ed. Grand Rapids: Eerdmans.

Westcott, B F \& Hort, F J A 1907. The divisions of the First Epistle of St John. Exp $7 / 3,481-493$. 